\title{
Mempelajari Pertumbuhan dan Produktivitas Tebu (Saccharum Officinarum. L) dengan Masa Tanam Sama pada Tipologi Lahan Berbeda
}

\author{
Study Growth and Productivity of Sugar Cane (Saccharum officinarum L.) With a Period of Planting is \\ Same at Different Typology of Land
}

\section{Bagustianto Ardiyansyah dan Purwono*}

Departemen Agronomi dan Hortikultura, Fakultas Pertanian, Institut Pertanian Bogor (Bogor Agricultural University), Jl. Meranti, Kampus IPB Darmaga, Bogor 16680, Indonesia Telp.\&Faks.62-251-8629353 e-mail agronipb@indo.net.id

*Penulis untuk korespondensi : purwono@yahoo.co.id

Disetujui 14 November 2015 /Published online 12 Desember 2015

\begin{abstract}
The apprentice activities was held in PG. Cepiring, Kendal, Central of Java in 4 months which was started from February $14^{\text {th }} 2011$ until June $14^{\text {th }} 2011$. The purpose of this activity is to study the management of sugarcane cultivation growth and productivity at the same plant in different typologies of low land irrigated and dry land. The differences of two land cultivation is an aspect of sewer mantenence. In irrigated fields gutter maintenance is very important because if not done will result desruption of sewer deepening cane growth.Primary data is data obtained that had an effect on growth and productivity of sugarcane namely estimation production, stem height, stem diameter, number of segments, number of stems, stem weight, and brix value. The observations show that the condition of irrigated land and rainfed land or upland did not show significantly different effect on the variables plant height, number of segments. While the time for sugarcane mill that accord with the planting of sugarcane is not maximized so that the growth of plants is not correspond with the time of planting because not according to the typologi of land.
\end{abstract}

Keyword: sugar cane, typology of land, productivity

\begin{abstract}
ABSTRAK
Kegiatan magang dilaksanakan di PG. Cepiring, Kendal, Jawa Tengah dalam 4 bulan yang dimulai dari 14 Februari 2011 sampai 14 Juni 2011. Tujuan dari kegiatan ini adalah untuk mempelajari pengelolaan budidaya tebu dan produktivitas di pabrik yang sama di berbagai tipologi dataran rendah irigasi dan lahan kering. Perbedaan dari dua budidaya lahan merupakan aspek pemeliharaan saluran pembuangan. Di sawah irigasi pemeliharaan selokan sangat penting karena jika tidak dilakukan akan mengakibatkan terganggunya memperdalam saluran pembuangan pertumbuhan tebu. Data primer adalah data yang diperoleh dari efek pertumbuhan dan produktivitas tebu yaitu estimasi produksi, tinggi batang, diameter, jumlah segmen batang, jumlah batang, batang berat, dan nilai brix. Pengamatan menunjukkan bahwa kondisi lahan irigasi dan tadah hujan atau lahan kering tidak menunjukkan pengaruh yang berbeda secara signifikan pada variabel tinggi tanaman dan jumlah segmen. Sedangkan waktu yang selaras untuk pabrik tebu dengan penanaman tebu belum maksimal sehingga pertumbuhan tanaman tidak sesuai dengan waktu tanam karena tidak sesuai dengan Typologi tanah.
\end{abstract}

Kata kunci : produktivitas, tebu, tipologi lahan 


\section{PENDAHULUAN}

Gula merupakan salah satu kebutuhan pokok rakyat Indonesia, akan tetapi produksi gula saat ini belum mampu mencukupi kebutuhan rakyat Indonesia. Target pencapaian swasembada gula nasional pada tahun 2014 mengharuskan pemerintah untuk meningkatkan produksi dan produktivitas tebu. Menurut Direktorat Jendral Perkebunan (2011) pabrik gula di Indonesia saat ini berjumlah 61 pabrik gula dengan kapasitas giling 220000 TCD (ton cane per day) dengan luas areal perkebunan tebu sekitar 436000 ha. Sasaran pada tahun 2014 Indonesia dapat melakukan swasembada gula dengan produksi sebesar 5.7 juta ton. Peningkatan jumlah produksi tersebut ditujukan untuk memenuhi kebutuhan nasional baik untuk yang konsumsi ataupun untuk industri.

Total produksi gula pada tahun 2008 adalah 2.67 juta ton, kemudian semakin menurun pada tahun 2009 sebesar 2.5 juta ton dan pada tahun 2010 sebedsar 2.23 juta ton dan menurut hasil taksasi produksi 2011 akan meningkat lagi menjadi 2.57 juta ton (Dewan Gula Indonesia, 2011).

Budidaya tebu dilakukan pada dua tipe lahan, yaitu lahan sawah dan lahan tegalan. Kedua tipe lahan tersebut memiliki potensi produktivitas yang sangat berbeda. Secara umum potensi produktivitas lahan sawah relatif lebih tinggi dibandingkan dengan lahan tegalan. Menurut Soepardi (1983) tebu adalah tanaman yang banyak memerlukan air, tetapi bukan tanaman air. Tingkat produksi erat dengan ketersediaan air, terutama untuk fase vegetatif awal dan tengah. Ketersedian air inilah yang merupakan masalah pada lahan tegalan. Tingkat produksi terkait erat dengan air dan iklim.

Menurut Djojosoewardhono

(1989) penentuan masa tanam tebu disesuaikan dengan iklim. Lokasi dengan sifat iklim yang terlalu basah sepanjang tahun dapat dilakukan penanaman pada saat menjelang musim kemarau atau pada bulan Mei - Agustus (masa tanam A), sedangkan untuk lokasi dengan sifat iklim yang relatif kering sepanjang tahun penanaman dilaksanakan pada awal musim kemarau atau pada bulan Oktober - Desember (masa tanam B). Penanaman menjelang musim kemarau dapat pula dilakukan untuk lokasi dengan pengairan yang baik. Masa tanam yang tepat bermanfaat untuk mendapatkan potensi rendemen yang tinggi.

Lahan sawah irigasi teknis adalah sawah yang memperoleh pengairan secara baik. Saluran pemberi air terpisah dari saluran pembuangan agar penyediaan dan pembagian irigasi dapat sepenuhnya diatur dan diukur dengan mudah (Indriani dan Sumiarsih, 1992). Menurut Sumantri (1989) lahan tegalan adalah lahan yang sumber air utamanya berasal dari curah hujan, dengan hanya mengandalkan adanya musim penghujan mengakibatkan distribusi dan frekuensi air tidak dapat diatur dan teknik budidaya yang digunakan perlu mendapatkan perhatian yang khusus.

Perbedaan lingkungan tumbuh tanaman tebu pada tipe lahan yang berbeda, menyebabkan karakteristik pertumbuhan agronomis tanaman tebu yang tumbuh diantara kedua tipe lahan tersebut akan berbeda. Lahan sawah irigasi relatif akan memiliki karakteristik pertumbuhan yang lebih baik dibandingkan pertumbuhan tebu pada lahan tegalan. Keterbatasan sumberdaya lahan (lingkungan) menyebabkan budidaya tebu harus dilakukan dengan tata cara yang baik dengan menyesuaikan terhadap lingkungan.

Tujuan dari penelitian ini adalah mempelajari pengelolaan budidaya tebu dengan masa tanam sama pada tipologi lahan sawah dan tegalan, menganalisis dan mengidentifikasi faktor - faktor yang mempengaruhi produktivitas dan pertumbuhan tebu pada masa tanam sama pada tipologi lahan sawah dan tegalan, dan mencari solusi pemecahan masalah terkait masalah pergeseran masa tanam A ke masa tanam B di lahan sawah.

\section{METODE PENELITIAN}

Kegiatan penelitian dilaksanakan selama 4 bulan, dimulai pada tanggal 14 Februari 2011 sampai 14 Juni 2011 di PG. Cepiring, PT Industri Gula Nusantara, Kendal, Jawa Tengah. Kegiatan magang dilakukan menggunakan metode secara langsung yaitu dengan bekerja secara langsung di lapangan. Metode secara langsung yang dilakukan selama magang, yaitu kegiatan yang menyangkut aspek teknis dan manajerial, serta aspek khusus. Pada aspek teknis penulis bekerja langsung di lapang sebagai Karyawan Harian Lepas (KHL). Kegiatannya KHL meliputi pengolahan lahan, persiapan bahan tanam, penanaman, pemeliharaan, pemanenan. Pada aspek manajerial mahasiswa bekerja sebgai pendamping mandor kebun dan pendamping Sinder Kebun Wilayah (SKW). Pada aspek khusus yang diperdalam oleh penulis yaitu mempelajari produktivitas dan pertumbuhan tebu dengan masa tanam sama pada tipologi lahan berbeda. Kegiatan ini mempelajari produktivitas masa tanam $\mathrm{B}$ dengan lahan sawah irigasi teknis dibandingkan dengan lahan tegalan.

Data diambil dari 2 KTG yaitu Kebun Ngasinan (sawah irigasi) dengan luasan 2.48 ha dan Kebun Gondang (tegalan) dengan luasan 5.18 
ha dengan varietas yang sama yaitu Bululawang (BL). Pengamatan dilaksanakan setiap 2 minggu. Pada setiap kebun diamati 5 petak sebagai ulangan. Setiap petak diamati sebanyak 4 juringan dengan panjang $2 \mathrm{~m}$ tiap juringan. Juringan yang diambil untuk sampling terletak pada juring ke 12, 24, 26, dan 48. Data primer yang didapat berupa data yang mempengaruhi pertumbuhan dan produktivitas tebu yaitu panjang batang, diameter batang, jumlah ruas, jumlah batang, taksasi produksi, nilai brix. Data sekunder yang didapat dari kebun berupa arsip kebun yang meliputi letak geografis dan topografi kebun, keadaan lingkungan tumbuh, kondisi areal dan tanaman, organisasi dan manajemen perusahaan, produksi PG. Cepiring. Selain itu pengumpulan data sekunder berupa pengumpulan data penunjang dilakukan melalui bahan pustaka yang tersedia di perusahaan.

\section{KEADAAN UMUM}

Pabrik Gula Cepiring secara geografis terletak pada $109^{\circ} 40^{\prime}-110^{\circ} 18^{\prime}$ BT dan $6^{\circ} 32^{\prime}-$ $7^{0} 24$ ' LS. Lokasi PG. Cepiring terletak di Kecamatan Cepiring Kabupaten Kendal, Jawa tengah. Jarak dari Semarang sekitar $40 \mathrm{~km}$ ke arah barat. Wilayah kerja PG. Cepiring tersebar di berbagai wilayah yaitu wilayah Kendal, Batang Timur, Semarang Barat, Kabupaten Semarang dengan ketinggian yang bervariatif antara $10-$ $500 \mathrm{~m}$ di atas permukaan laut.

Total proyeksi luas KTG PG. Cepiring yaitu 2471 ha. Komposisi varietas tanaman yang digunakan PG. Cepiring tidak berimbang, yaitu 84.5\% kebun di PG. Cepiring menggunakan varietas masak tengah dan lambat varietas PSJT 941 dan Bululawang (BL) sedangkan kebun yang menggunakan varietas masak awal yaitu varietas PS 77 dan PS 881 hanya sebesar $15.5 \%$.

Kebun Ngasinan mempunyai luas sebesar 2.48 ha. Kebun Ngasinan merupakan salah satu kebun KmA PG. Cepiring yang ditanami varietas BL dengan jenis tanaman PC. Kebun ini terletak pada lahan sawah irigasi teknis sehingga pola budidayanya menggunakan sistem reynoso. Jenis tanah kebun Ngasinan adalah tanah Alluvial.

Kebun Gondang mempunyai luas sebesar 12.31 ha. Kebun terletak pada lahan tegalan. Kebun ini terdiri dari 5 blok yaitu blok A, B, C, D, E. Setiap blok memiliki varietas dan kategori tanaman yang berbeda. Gondang D merupakan kebun dengan kategori tanaman PC dengan luas areal 5.18 ha. Jenis tanah kebun Ngasinan adalah tanah Alluvial.

\section{HASIL DAN PEMBAHASAN}

\section{Pengusahaan lahan}

Permasalahan perolehan lahan seringkali menjadi masalah untuk PG. Cepiring. Tingginya harga sewa lahan yang menunjukkan tanaman tebu harus berkompetisi dengan komoditas dengan pola tanaman dominan merupakan salah satu penyebab pengusahaan lahan di wilayah PG. Cepiring menjadi sulit. Pengusahaan tembakau, bawang merah, padi, dan jagung pada wilayah PG. Cepiring menjadi komoditas saingan untuk pengusahaan lahan tebu.

Kekurangan areal menyebabkan PG. Cepiring tidak mampu memenuhi idle capacity yang tersedia. Pada tahun 2011 luas areal PG Cepiring seluas 2471 ha dengan kapasitas giling sebesar 1800 TCD dan hari giling 155 hari. Hal ini jauh dari luas areal yang dibutuhkan untuk memenuhi idle capacity PG. Cepiring yaitu seluas 4300 ha. Kekurangan areal yang disebabkan persaingan dengan komoditas lainnya mengharuskan PG. Cepiring untuk melakukan pengalihan budidaya tebu dari lahan sawah ke lahan tegalan/lahan kering.

Selain itu kekurangan areal lahan juga disebabkan struktur organisasi PG Cepiring yang kurang efisien, khususnya Bagian Tanaman. Bagian Tanaman yang kedudukannya berada di bawah Kepala Pabrik menyebabkan setiap kebijakan yang diambil harus mendapatkan persetujuan dari Kepala Pabrik diantaranya kebijakan pengembangan perluasan lahan. Kepala Pabrik mempunyai wewenang untukmelakukan kebijakan kepada bagian dibawahnya yaitu menyetujui atau membatalkan kebijakan yang akan diambil bagian dibawahnya.Hal inilah yang menyebabkan proses pengembangan areal sulit dilakukan Bagian Tanaman, karena PG Cepiring lebih memfokuskan untuk mengolah raw sugar dibandingkan dengan menggiling tebu.

Harga sewa lahan sawah yang tinggi juga menjadi alasan pengembangan perluasan areal lahan di PG Cepiring sulit dilakukan. Salah satu upaya yang dapat dilakukan untuk memenuhi kekurangan areal yaitu pengalihan budidaya tebu di lahan sawah ke lahan kering atau tegalan. Daerah Kabupaten Kendal bagian selatan dan Kabupaten Batang dapat dijadikan areal pengembangan perluasan areal. Selain harga sewa yang lebih murah dibandingkan harga sewa lahan sawah, lahan kering/tegalan di daerah tersebut masih banyak yang belum dimaksimalkan. Upaya yang dapat dilakukan oleh PG. Cepiring selain itu adalah dengan melakukan pendekatan dengan instansi terkait yaitu pihak pemerintah daerah, 
APTRI, serta memanfaatkan pihak - pihak yang dulu pernah mengikuti program TRI.

Adanya persaingan dengan komoditas lain menyebabkan terjadinya keterlambatan proses penyerahan lahan. Lamanya masa negosiasi antara pihak PG dan petani menyebabkan masa tanam tebu menjadi mundur. Masa tanam terbagi menjadi masa tanam A dan B. Masa tanam A merupakan masa tanam tebu yang dilakukan pada awal musim kemarau dan berakhir pada awal musim hujan (bulan Mei - Agustus) sedangkan pada masa tanam B masa tanam tebu yang dilakukan pada awal musim hujan (bulan Oktober - Desember). Pada masa tanam pola A budidaya tebu dilakukan pada lahan sawah berpengairan atau cukup irigasi sedangkan pada pola B budidaya tebu dilakukan pada lahan kering/tegalan/sawah tegalan yang mengandalkan pengairan dari curah hujan.

Proses keterlambatan penyerahan lahan mengakibatkan pergeseran masa tanam A dapat berubah menjadi masa tanam B. Pergeseran masa tanam karena keterlambatan penyerahan lahan dapat menyebabkan produktivitas lahan tidak maksimal. Kondisi lingkungan tumbuh menjadi salah satu faktor yang sangat menentukan tinggi atau rendahnya produktivitas lahan tersebut.

Penyerahan lahan untuk masa tanam A dilakukan paling lambat pada bulan Januari Februari, sehingga proses negosiasi lahan harus sudah dilakukan antara bulan Oktober September sedangkan penyerahan lahan untuk masa tanam B dilakukan paling lambat bulan April - Mei dengan proses negosiasi dimulai pada bulan Januari. Manajemen waktu yang baik dengan target yang jelas akan memperbaiki ketersedian lahan untuk penanaman.

\section{Pergeseran masa tanam}

Proses keterlambatan penyerahan lahan mengakibatkan pergeseran masa tanam A dapat berubah menjadi masa tanam B. Pergeseran masa tanam karena keterlambatan penyerahan lahan dapat menyebabkan produktivitas lahan tidak maksimal. Masa tanam A (Mei - Agustus) dilakukan di lahan sawah irigasi pada awal musim kemarau. Pengelolaan budidaya di lahan sawah irigasi pada masa tanam A berbeda dibandingkan dengan masa tanam B. Perbedaan budidaya terletak pada pengaturan sistem tata air (drainase), yaitu melakukan pendalaman got.

Pada masa tanam A ketersediaan air berasal dari air irigasi sehingga ketersediaan airnya dapat diatur sedemikian rupa. Kegiatan pendalaman got pada masa tanam A dapat dilakukan secara bertahap karena pada masa tanam A bertepatan dengan musim kemarau, selain itu karena pada saat musim hujan tiba kondisi tebu pada masa tanam A sudah mencapai umur $4-5$ bulan. Hal ini berbeda dengan masa tanam B (Oktober - Desember) yang dilakukan di awal musim penghujan. Kondisi tebu pada masa tanam B baru berumur 1 bulan sehingga solusinya adalah kegiatan pendalaman got harus dilakukan sekaligus, hal ini untuk menghindari terjadinya banjir di lahan.Hal ini terjadi pada kebun Ngasinan (sawah irigasi), sehingga kebun tersebut terjadi banjir dan terpaksa melakukan penanaman ulang. Tindakan penanggulangan pada lahan yang drainasenya kurang lancar sangat dibutuhkan. Menurut Suhadi et. al (1989) tindakan pertama adalah memperbaiki sistem drainase yaitu dengan menurunkan permukaan air tanah, setelah itu pengolahan tanah yang dalam serta perbaikan saluran drainase.

Menurut Indriani dan Sumiarsih (1992) kerugian apabila tebu ditanam di lahan sawah irigasi pada saat masa tanam $B$ adalah ketersediaan air yang terlampau banyak karena selain mendapatkan aliran air dari irigasi, air dari curah hujan akan memperbanyak ketersediaan air yang berakibat pertumbuhan tebu tidak maksimal. Selanjutnya Yusuf dan Hidayat (1989) menyatakan lahan tegalanapabila ditanam pada masa tanam B maka keuntungannya adalah ketersediaan air yang cukup karena pengaruh curah hujan dimanfaatkan untuk fase pertumbuhan terutama pertumbuhan tunas.

$$
\text { Mubyarto dan Daryati }
$$
mengemukakan bahwa perbedaan mendasar kedua jenis lahan tersebut adalahkondisi tanah (drainase) yang membawa konsekuensi pada jenis budidaya yang diharapkan dapat memberikan kondisi yang cocok bagi pertumbuhan tanaman. Pada lahan sawah penanaman tebu pada masa tanam B mempunyai dampak negatif karena apabila terjadi kondisi banjir, kondisi tanaman masih muda atau belum mencapai pertumbuhan yang maksimum.

Drainase yang baik ditandai dengan kondisi tanah yang dipenuhi air secara berlebih mengalami penurunan kadar air tidak lebih dari 24 jam. Drainase buruk ditandai dengan kondisi tanah yang dipenuhi air mengalami penurunan kadar air jenuh dalam waktu lama. Faktor penyebab utama drainase yang buruk diantaranya adalah muka air tanah yang dangkal dan pemadatan tanah.

Drainase yang buruk menyebabkan dampak yang tidak menguntungkan terhadap perkembangan akar tanaman tebu. Akar akan berkembang secara horizontal sehingga sangat peka terhadap kekeringan sewaktu tanaman muda dan karena tanah kekurangan oksigen pada musim 
hujan akar segera membusuk, peka terhadap penyakit terutama bakteorosis dan kemudian berlanjut pada kematian pada tebunya (Pamenan, et. al, 1989). Tebu merupakan tanaman yang menghendaki air yang cukup banyak.Kebutuhan air (irigasi) untuk tebu berbanding lurus dengan sifat fase pertumbuhan karena tanaman ini memerlukan air yang cukup banyak pada awal sampai dengan pertengahan waktu biologis pertumbuhan. Setelah itu,pada fase kemasakan menghendaki kebutuhan air yang sangat sedikit.

\section{Kondisi kebun Ngasinan dan kebun Gondang}

Kebun Ngasinan merupakan salah satu kebun PG. Cepiring yang ditanami varietas BL dengan jenis tanaman PC.Kebun Ngasinan merupakan kebun dengan sawah irigasi teknis sehingga pola budidayanya menggunakan sistem reynoso.Penggunaan sistem reynosoyang dilakukan di lahan berpengairan idealnya dilakukan penanaman pda masa tanam I yaitu pada bulan Mei - Agustus. Akan tetapi budidaya di kebun Ngasinan dilakukan pada masa tanam B yaitu pada bulan Oktober sehingga terdapat 2 blok dari 3 blok yang terkendala pertumbuhannya karena masalah drainase tersebut.

Masalah utama yang terdapat di kebun Ngasinan adalah kendala pembuangan air.Awal tanam kebun Ngasinan adalah pada awal musim penghujan sehingga berakibat pasokan air yang berlebihan di lahan, selain itu juga lahan ini berdekatan dengan lahan persawahan petani sehingga menyulitkan dalam pembuangan air.Pembuangan air pada kebun Ngasinan merupakan pemasukan air bagi kebun petani. Seringkali saluran air ditutup oleh petani sehingga air menggenang di got dan menyebabkan kandungan air tanah yang tinggi yang menghambat pertumbuhan tebu pada tahap awal. Pemeliharaan yang dilakukan untuk mengatasi masalah drainase ini dengan memperdalam seluruh got serta melakukan pengecekan seriap hari dan saat terjadi hujan pada saluran pembuangan. Hal ini untuk mengantisipasi tingginya air pada lahan.

Pada kondisi drainase yang tidak baik pertunasan bibit bagal yang ditanam tidak terlalu baik sehingga membutuhkan penanaman ulang.Hal ini diakibatkan karena keadaan tanah yang terlalu banyak mengandung air dan kondisi tanah yang terlalu banyak lempung, padahal varietas BL tidak menyukai drainase yang buruk serta lahan berat. Setelah penanaman ulang juga terdapat kendala yang sama, namun tidak separah penanaman yang pertama. Dengan kondisi tersebut dilakukan penyulaman menggunakan rayungandari kebun bibit maupun bibit awildari juringan yang banyak terdapat tunas yang tumbuh.

Kebun Gondang adalah kebun dengan tipe lahan tegalan. Kebun ini terdiri dari empat blok yaitu blok A, B, C dan D. Secara keseluruhan kondisi di kebun Gondang blok D cukup baik jika dibandingan dengan kebun Ngasinan. Pertumbuhan tebu lebih baik dilihat dari tinggi batang, diameter batang, dan jumlah batang pada pengamatan terakhir. Kegiatan pemeliharaan di kebun Ngasinan dan kebun Gondang sama tetapi dilihat dari pertumbuhannya berbeda karena lahan untuk kebun Gondang yang terletak di lahan tegalan yang pengairannya mengandalkan dari turunnya air hujan telah sesuai dengan pola tanam.

Masalah pada kebun Gondang D adalah pada saat awal penanaman lahan harus menunggu datangnya air hujan sehingga pertumbuhan pada masa awal sedikit terganggu.Sedangkan masalah utama pada kebun ini adalah banyaknya gulma yang tumbuh.Hal ini dikarenakan penanaman yang bertepatan dengan musim penghujan sehingga pengendalian secara kimiawi tidak mampu mengendalikan pertumbuhan gulma dengan baik.Kondisi ini berakibat pengendalian gulma bertumpu pada penyiangan yang dilakukan secara manual.

Pada fase pertumbuhan data primer yang diamati adalah tinggi tanaman, jumlah batang per juring, jumlah ruas per batang, diameter batang dan bobot batang per meter (Tabel 8). Dengan mengamati peubah pertumbuhan dapat diketahui sejauh mana karakter pertumbuhan masing masing mampu beradaptasi pada berbagai kondisi masa tanam, yang pada gilirannya akan menentukan hasil panen. Menurut Sumantri (1989), komponen pertumbuhan tanaman yang menentukan hasil tebu antara lain tinggi batang, jumlah batang, dan diameter batang. Kontribusi tiga komponen tersebut terutama terhadap hasil bobot tebu.

Perpanjangan tinggi batang memegang peranan penting dalam menentukan perolehan bobot tebu dan rendemen. Proses pemanjangan batang merupakan pertumbuhan yang didukung dengan perkembangan beberapa bagian tanaman perkembangan tajuk daun, perkembangan akar, dan pemanjangan batang. Hasil pengamatan tinggi tanaman memperlihatkan adanya perbedaan kecepatan pertumbuhan tanaman pada masing masing tipologi lahan.Pada kebun Ngasinan pertumbuhan terlihat lebih lambat jika dibandingkan dengan kebun Gondang.

Hal ini dikarenakan pada waktu fase pemanjangan batang, intensitas sinar matahari yang sedikit mengakibatkan pemanjangan batang tidak optimal. Sinar matahari sangat diperlukan 
dalam proses fotosintesis yang selanjutnya akan berpengaruh dalam pertumbuhan dan hasil panen tebu. Menurut Williams (1979) bahwa tanaman tebu adalah tanaman yang menyenangi matahari.Selain itu perbedaan kecepatan pertumbuhan tinggi tanaman disebabkan oleh ketersediaan air pada masing - masing lahan.Masalah drainase menghambat pemanjangan batang pada lahan kebun Ngasinan karena tingginya curah hujan tidak diimbangi dengan pemeliharaan saluran pembuangan yang baik.Tetapi melalui uji-ttipologi tanaman tidak menunjukkan pengaruh yang berbeda nyata antara kedua lahan tersebut terhadap tinggi tanaman.

Proses pemanjangan batang sangat berkaitan dengan proses pembentukan ruas tebu. Pembentukan ruas tebu selama fase pemanjangan batang dengan panjang ruas rata - rata mencapai $15-20 \mathrm{~cm}$. Fase ini berlangsung pada $3-9$
bulan.Dari hasil pengamatan yang telah dilakukan dapat dilihat bahwa pembentukan ruas tebu normal yaitu sekitar $3-4$ ruas tebu per bulan.Hal ini menunjukkan tipologi lahan tidak berpengaruh nyata terhadap pertumbuhan jumlah ruas.

Faktor pemeliharaan tebu yaitu pemupukan dan pembumbunan sangat berpengaruh terhadap besar atau kecilnya diameter batang.Pengamatan diameter batang dilakukan padawatu tebu berumur 23 MST - 35 MST. Hasil pengamatan disajikan pada Tabel 8.Pada tabel tersebut dapat dilihat bahwa pada awal pengamatan hingga akhir pengamatan menunjukkan bahwa diameter tebu kebun Gondang lebih besar dan berbeda nyata dengan diameter tebu kebun Ngasinan. Hasil ini menujukkan pengaruh pemeliharaan terhadap pertumbuhan diameter batang.

Tabel 1. Pengamatan fase pertumbuhan Kebun Ngasinan dan Kebun Gondang

\begin{tabular}{|c|c|c|c|c|c|}
\hline \multirow[b]{2}{*}{ Peubah } & \multirow[b]{2}{*}{ Kebun } & \multicolumn{3}{|c|}{ Umur Tebu } & \multirow[b]{2}{*}{ MST $^{35}$} \\
\hline & & $\begin{array}{c}23 \\
\text { MST }\end{array}$ & $\begin{array}{c}27 \\
\text { MST } \\
\end{array}$ & $\begin{array}{c}31 \\
\text { MST } \\
\end{array}$ & \\
\hline Tinggi & Ngasinan & $1.39 \mathrm{a}$ & $1.62 \mathrm{a}$ & $1.86 \mathrm{a}$ & $2.03 \mathrm{a}$ \\
\hline$(\mathrm{m})$ & Gondang & $1.39 \mathrm{a}$ & $1.70 \mathrm{a}$ & $1.99 \mathrm{a}$ & $2.20 \mathrm{a}$ \\
\hline Diameter & Ngasinan & $2.49 \mathrm{a}$ & $2.52 \mathrm{a}$ & $2.52 \mathrm{a}$ & $2.52 \mathrm{a}$ \\
\hline$(\mathrm{cm})$ & Gondang & $2.79 \mathrm{~b}$ & $2.80 \mathrm{~b}$ & $2.80 \mathrm{~b}$ & $2.80 \mathrm{~b}$ \\
\hline Jumlah & Ngasinan & $14 \mathrm{a}$ & $17 \mathrm{a}$ & $21 \mathrm{a}$ & $24 \mathrm{a}$ \\
\hline Ruas & Gondang & $13 \mathrm{a}$ & $17 \mathrm{a}$ & $20 \mathrm{a}$ & $24 \mathrm{a}$ \\
\hline $\begin{array}{l}\text { Bobot } \\
\text { Batang/m }\end{array}$ & Ngasinan & $0.45 \mathrm{a}$ & $0.46 \mathrm{a}$ & $0.46 \mathrm{a}$ & $0.46 \mathrm{a}$ \\
\hline$(\mathrm{kg})$ & Gondang & $0.51 \mathrm{~b}$ & $0.51 \mathrm{~b}$ & $0.51 \mathrm{~b}$ & $0.51 \mathrm{~b}$ \\
\hline Jumlah & Ngasinan & $73 \mathrm{a}$ & $70 \mathrm{a}$ & $61 \mathrm{a}$ & $49 \mathrm{a}$ \\
\hline Batang & Gondang & $73 \mathrm{a}$ & $64 \mathrm{~b}$ & $61 \mathrm{a}$ & $58 \mathrm{~b}$ \\
\hline nber & $: \mathrm{Ha}$ & & & & \\
\hline
\end{tabular}

Berdasarkan pengamatan di kebun Ngasinan maupun kebun Gondang diameter tebu termasuk dalam kriteria sedang. Hal ini termasuk normal karena menurut P3GI (2009) varietas BL memang mempunyai sifat agronomis diameter batang dari sedang sampai besar. Diameter batang dapat ditingkatkan apabila pada saat pemupukan pada kedua kebun tidak terlambat karena harus menunggu ketersediaan pupuk. Selain itu pekerjaan pembumbunan juga harus diperbaiki karena pada saat pengamatan tanah hasil pembumbunan sebagian besar tidak mencakup batang tebu.

Bobot tebu sering menjadi masalah dalam industri pergulaan saat ini karena bobot tebu merupakan salah satu faktor untuk mengetahui hablur tebu.Bobot tebu juga berkolerasi positif dengan diameter batang dan tinggi batang. Semakin besar diameter batang dan tinggi batang maka bobot tebu yang diperoleh akan semakin besar. Dari Tabel 8 hasil bobot tebu pada 23 MST - 35 MST menunjukkan pengaruh yang berbeda nyata.Dilihat dari hasil pengamatan tersebut kemampuan adaptasi tebu pada lahan kebun Gondang lebih optimal daripada kebun Ngasinan.

Hasil pengamatan jumlah batang tebu dapat dilihat pada Tabel 8. Pada awal pengamatan, kedua kebun mempunyai jumlah batang yang sama yaitu 73 , tetapi terjadi kecenderungan pada setiap pengamatan selanjutnya jumlah batang yang diamati mengalami penurunan. Pada pengamatan terakhir 
rata - rata kebun Ngasinan terdapat 49 batang per juringan sedangkan kebun Gondang rata - rata terdapat batang per juringan sebanyak 58 batang.Hal ini menunjukkan bahwa menjelang tebang jumlah batang sebagian besar banyak yang mati. Penurunan jumlah batang ini ditentukan oleh jumlah anakan yang terbentuk selama proses pertumbuhan dan persaingan antar anakan dalam perebutan unsur hara dan faktor tumbuh lainnya.

Berdasarkan uji-t pada taraf nyata $5 \%$ dapat dilihat bahwa tinggi tanaman, jumlah ruas dan jumlah batang pada 3 pengamatan awal menunjukkan perbedaan tipologi lahan tidak mempunyai pengaruh nyata terhadap pertumbuhan tanaman sedangkan pada peubah diameter batang, bobot per meter dan pengamatan terakhir pada jumlah batang menunjukkan perbedaan tipologi lahan mempunyai pengaruh yang berbeda nyata terhadap pertumbuhan tanaman. Pada pengamatan terakhir jumlah batang, jumlah batang berbeda nyata sehingga harus dilakukan pemeliharaan yang lebih baik dengan cara waktu pemupukan yang lebih tepat serta penggunaan bibit yang bermutu.

Perhitungan brix digunakan untuk menghitung besarnya nilai padatan terlarut. Cara perhitungan brix dilakukan dengan menggunakan alat hand refractometer, yaitu alat yang digunakan untuk mengukur padatan yang terlarut dalam suatu larutan. Cara pengukurannya adalah dengan meneteskan nira yang terkandung di dalam batang tebu ke kaca berwarna biru kemudian ditutup menggunakan penutup dan kemudian angka hasil proses brix dapat terbaca dengan melihat lubang yang terdapat pada bagian bawah alat tersebut. Pengukuran brix pada tebu terbagi menjadi 3 bagian batang yaitu bagian atas, tengah dan bawah. Tebu dikatakan mempunyai tingkat kemasakan yang baik apabila nilai brix pada setiap bagian batang sama. Menurut standar dari PG. Cepiring, tebu dapat ditebang apabila nilai brixdi atas angka 25.

Hasil pengamatan pada nilai brix menunjukkan hasil yang berbeda nyata pada kedua kebun (Tabel 10).Kebun Gondang mempunyai nilai brix yang lebih baik.Hasil perhitungan brix juga dapat digunakan untuk menghitung rendemen secara cepat atau rendemen sementara. Menurut Purwono (2003) terdapat korelasi yang nyata antara nilai brix (B) yang diukur dengan rendemen $(\mathrm{R})$ dengan $r^{2}=0.82$ dan persamaan regresinya adalah $\mathrm{R}=-0.0254+$ 0.4746 B.

Tabel 2. Pengamatan Brix pada Kebun Ngasinan dan Kebun Gondang

\begin{tabular}{ccccccccc}
\hline \multirow{2}{*}{ Kebun } & \multicolumn{9}{c}{ Batang } & \multirow{2}{*}{ Rata-rata } & Rs \\
\cline { 2 - 6 } & 1 & 2 & 3 & 4 & 5 & & $16 \mathrm{a}$ & 7.38 \\
Ngasinan & $16 \mathrm{a}$ & $14 \mathrm{a}$ & $16 \mathrm{a}$ & $15 \mathrm{a}$ & $17 \mathrm{a}$ & & $21 \mathrm{~b}$ & 9.94 \\
Gondang & $20 \mathrm{~b}$ & $20 \mathrm{~b}$ & $23 \mathrm{~b}$ & $20 \mathrm{~b}$ & $22 \mathrm{~b}$ & & 2 \\
\hline
\end{tabular}

Sumber : Hasil Pengamatan (2011)

Keterangan : Angka yang diikuti huruf yang sama pada kolom yang berbeda tidak berbeda nyata pada $U j i-t$ dengan taraf $5 \%$

Hasil rendemen menunjukkan besarnya kandungan gula dalam setiap kuintal yang digiling. Besarnya nilai rendemen dipengaruhi oleh faktor dari varietas tebu, lingkungan, budidaya, serta proses pabrikasi. Penghitungan rendemen sementara dapat dilakukan dengan cara cepat dengan mengambil nira tebu yang akan digiling menggunakan hand refractometer. Pada Tabel 2 menunjukkan nilai rendemen sementara kebun Gondang lebih tinggi daripada kebun Ngasinan.Hal ini menunjukkan pengaruh lahan dan budidaya memberikan pengaruh yang berbeda nyata terhadaphasil rendemen sementara.

\section{Produktivitas tebu kebun Ngasinan dan kebun Gondang}

Potensi lahan sawah untuk menghasilkan produktivitas gula cukup tinggi.Tebu merupakan tanaman yang secara spesifik mengehendaki kebutuhan air yang cukup banyak pada periode awal pertumbuhan sampai periode tengah pertumbuhan, namun menjelang terjadinya fase pemasakan tanaman ini membutuhkan air yang sedikit. Pada akhir periode pengelolaan tebu, yaitu pada proses pemanenan hasil menghendaki kondisi air tanah yang cukup kering guna melancarkan proses pasca panen. Di lapangan, kondisi lahan dengan pengaturan ketersediaan air yang begitu dinamis hanya dapat tercapai di lahan sawah yang beririgasi.

Berdasarkan Tabel 3 produktivitas antara kebun Ngasinan dan kebun Gondang berbeda nyata. Kebun Ngasinan dengan habitat yang cocok untuk tebu mempunyai taksasi produksi yang lebih rendah dibandingkan dengankebun Gondang.Perbedaan hasil taksasi produksi antara kedua lahan tersebut dipengaruhi oleh beberapa faktor diantaranya pengolahan tanah, pengendalian air baik irigasi maupun drainase, serta teknik budidaya. 
Komponen hasil hablur secara teoritis merupakan perkalian dari hasil bobot tebu dengan nilai rendemen. Berdasarkan hasil perhitungan rendemen sementara terlihat adanya interaksi antara masa tanam tebu dengankondisi lahan terhadap produktivitas hasil hablur yang dihasilkan. Pada Tabel 3 menunjukkan masa tanam B pada kebun Gondang dengan lahan tegalan memberikan hasil hablur yang berbeda nyata dengan kebun Ngasinan. Produktivitas hablur di kebun Ngasinan sebesar 4.13 ton/ha sedangkan kebun Gondang sebesar 7.91 ton/ha. Produktivitas tebu yang dihasilkan kebun Ngasinan sebesar 55.96 ton/ha sedangkan untuk kebun Gondang sebesar 79.59 ton/ha.

Tabel 3. Hasil taksasi produksi kebun Ngasinan dan kebun Gondang

\begin{tabular}{lcc}
\hline \multicolumn{1}{c}{ Peubah } & \multicolumn{2}{c}{ Kebun } \\
\cline { 2 - 3 } & $\begin{array}{c}\text { Ngasinan } \\
\text { (sawah irigasi) }\end{array}$ & $\begin{array}{c}\text { Gondang } \\
\text { tegalan) }\end{array}$ \\
\hline Tinggi (m) & $2,03 \mathrm{a}$ & $2,2 \mathrm{a}$ \\
Bobot Batang/m (kg) & $0,46 \mathrm{a}$ & $0,51 \mathrm{~b}$ \\
Jumlah Batang/juring & $49 \mathrm{a}$ & $58 \mathrm{~b}$ \\
Faktor Juring & $1223 \mathrm{a}$ & $1223 \mathrm{a}$ \\
Produktivitas Tebu (ton/ha) & $55,96 \mathrm{a}$ & $79,59 \mathrm{~b}$ \\
Rendemen Sementara & 7.38 & 9.94 \\
Hablur Gula (ton/ha) & $4.13 \mathrm{a}$ & $7.91 \mathrm{~b}$ \\
\hline Sumber Hasil Pengamatan (2011) & Angka yang diikuti huruf yang sama pada kolom yang berbeda tidak berbeda nyata pada Uji-t dengan taraf 5\%
\end{tabular}

Potensi produktivitas antara lahan sawah irigasi dengan lahan tegalan tidak jauh berbeda jika ditanam sesuai dengan masa tanam. Tetapi apabila penanaman dilakukan sesuai dengan masa tanam maka potensi produktivitas akan berbeda. Hal ini karena lahan tidak bisa dipaksa untuk memberikan potensi produktivitas yang tinggi jika kesesuaian lingkungan tidak mendukung untuk pertumbuhan.

\section{KESIMPULAN}

Pengelolaan budidaya tebu di kebun Ngasinan (sawah irigasi) pada masa tanam B berbeda dengan masa tanam A. Perbedaan terletak pada perlakuan teknis tata air yaitu kegiatan pendalaman got. Pada masa tanam B pendalaman harus dilakukan sekaligus untuk mengantisipasi datangnya musim penghujan yang bertepatan dengan awal tumbuh tanaman, berbeda dengan masa tanam A yang pendalaman got dilakukan berangsur karena awal penanaman dilakukan pada musim kemarau. Kondisi di kebun Ngasinan menunjukkan bahwa pengaturan drainase pada kebun Ngasinan belum maksimal karena proses pendalaman got telat dan dilakukan secara berangsur sehingga menyebabkan terjadinya banjir dan pertumbuhan vegetatif awal terganggu.

Hasil pengamatan pada kedua kebun menunjukkan bahwa faktor - faktor yang mempengaruhi produktivitas tebu adalah peubah jumlah batang dan bobot batang sedangkan pertumbuhan tebu sangat dipengaruhi oleh faktor sanitasi kebun. Kebun Gondang yang tidak terkendala pada masalah got menunjukkan pertumbuhan tebu yang lebih baik dibandingkan dengan kebun Ngasinan. Sedangkan perbedaan tipologi lahan pada masa tanam yang sama tidak menunjukkan pengaruh yang berbeda nyata pada peubah tinggi tanaman, dan jumlah ruas pada fase pertumbuhan.

Tingginya harga sewa tanah karena persaingan dengan komoditi lain pada lahan sawah mengakibatkan keterlambatan penanaman kebun tebu giling dari masa tanam A ke masa tanam B yang menyebabkan produktivitas tebu dan gula di lahan sawah lebih rendah daripada lahan tegalan.

\section{DAFTAR PUSTAKA}

Dewan Gula Indonesia. 2011. Ketersedian Gula Nasional Tahun 2011. Jakarta (ID) : Dewan Gula Indonesia

Direktorat Jenderal Perkebunan. 2011. Pertemuan Koordinasi Persiapan Pelaksanaan. Kegiatan Tanaman Semusim Tahun 2011[Internet].[Diunduh 2011 Juli 15]. Tersedia pada : http://ditjenbun.deptan.go.id/budtansim/. 
Djojosoewardhono, S. A. 1989. Peranan tebu dan faktor lingkungan tumbuh terhadap tingkat produktivitas bagi tebu di lahan kering. Pasuruan (ID) : Prosiding Seminar Budidaya Lahan Kering. Pasurua

Indrajati, R. P. 2008. Evaluasi perubahan kualitas tanah sawah irigasi teknis di kawasan industri sub das Bengawan Solo daerah Kabupaten Karanganyar. [skripsi]. Surakarta (ID) : Universitas Sebelas Maret.

Indriani, Y. H., Sumiarsih, E. 1992. Pembudidayaan Tebu di Lahan Sawah dan Tegalan. Jakarta (ID) : Penebar Swadaya.

Kuntohartono, T. 1987. Budidaya tebu lahan kering dan pengairannya. Majalah Gula Indonesia. XVI (1): F $16-22$.

Manggabarani, A. 2008. Momentum seabad kebangkitan nasional. Gula Indonesia. Vol XXXII (1):3-5.

Mubyarto, Daryati. 1991. Gula: Kajian Sosial Ekonomi. Jogjakarta (ID) : Aditya Media.

Pamenan, S. B., D. Siahaan, Lannita. 1989. Pengembangan Tebu Lahan Kering. Pasuruan (ID) : Prosiding Seminar Budidaya Lahan Kering. $615-627$.

Purwono. 2003. Penentuan Rendemen Gula Tebu Secara Cepat. Paper Individu. Institut Pertanian Bogor. Bogor. 6 hal.

PT. Perkebunan Nusantara VII. 1997. Vademecum Tanaman Tebu. PT. Perkebunan Nusantara VII Lampung. Lampung (ID) : PPN VII.
Setyamidjaja, D., Azharni, H. 1992. Tebu Bercocok Tanam dan Pasca Panen. CV. Jakarta (ID) : Yasaguna. 152 hal.

Soepardi, G. 1983. Sifat dan Ciri - Ciri Tanah. Bogor (ID) : Departemen Ilmu Tanah, Institut Pertanian Bogor. 591 hal.

Sudiatso, S. 1988. Bertanam Tebu. Bogor (ID) : Departemen Agronomi dan Hortikultura, Institut Pertanian Bogor. 43 hal.

Suhadi, Sumoyo, Pawirosemadi, M 1989. Beberapa Masalah Tanah di Perkebunan Tebu di Lahan Kering di Luar Jawa. Pasuruan (ID) : Prosiding Seminar Budidaya Lahan Kering. $360-367$.

Sumantri, A. 1989. Interaksi Varietas Tebu dan Masa Tanam di Lahan Tegalan PG. Jatiroto. Pasuruan (ID) : Prosiding Seminar Budidaya Lahan Kering. Pasuruan.428 - 435.

Sutardjo, E. R. M. 2002. Budidaya Tanaman Tebu. Jakarta (ID) : Bumi Aksara. 76 hal.

Yusuf, L., Hidayat, T. 1989. Pengalihan Budidaya Tebu Lahan Sawah ke Lahan Kering di PG. Sindang Laut, PTP XIV Cirebon. Pasuruan (ID) : Prosiding Seminar Budidaya Lahan Kering. $628-631$.

Williams, N. C. 1979. Sugarcane is The Agronomy of The Maajor Tropical. New York (USA) : Oxford University Press. 50 - 64. 